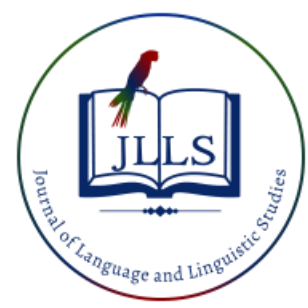

Available online at www.jlls.org

JOURNAL OF LANGUAGE AND LINGUISTIC STUDIES

ISSN: 1305-578X

Journal of Language and Linguistic Studies, 17(3), 1566-1581; 2021

\title{
Strategies for second language learning in EFL textbooks of Saudi high school: A content analysis
}

\author{
Kholoud A. Alwehebi a 1 iD, Wafaa A. Ghareeb ${ }^{\text {b }}$ iD \\ APA Citation: \\ ${ }^{a, b}$ Imam Abdulrahman Bin Faisal University, Saudi Arabia \\ Alwehebi, K.A., Ghareeb, W.A. (2021). Strategies for second language learning in EFL textbooks of Saudi high school: A content analysis. \\ Journal of Language and Linguistic Studies, 17(3), 1566-1581. Doi: 10.52462/jlls.113 \\ Submission Date: 18/05/2021 \\ Acceptance Date:20/08/2021
}

\begin{abstract}
This paper presents a content analysis study that aimed at investigating the L2 learning strategies (LLS) across three units in each of the six textbooks in the new set of secondary school EFL textbooks, 'Mega Goal', based on the lists of learning strategies adapted from Chamot and Schmitt: (vocabulary learning strategies, reading strategies and, speaking and writing strategies). Content analysis undertaken by the researchers brought to light the need to develop a framework and thereby embark upon evolving appropriate strategies for teaching-learning of EFL to the secondary school students in Saudi Arabia. The results also show that there is no explicit presentation of LLS. However, some vocabulary and most reading and writing strategies searched for are implicitly used in the instructions in the language activities in the analyzed books. The study concludes that the books need to be modified by adding explicit instruction of learning strategies and including more vocabulary strategies. It is suggested that teachers should be given orientation training programmes for proper appreciation of the teaching-learning strategies. The paper ends with suggestions for further research.
\end{abstract}

Key words: Language learning strategies; Secondary education; EFL textbooks; Content analysis

\section{Introduction}

Textbooks are considered the main formal, accredited, and significant materials for school language courses. Such books are at the centre-stage as far as the whole process of making secondary school level students learn the EFL with ease and interest is concerned. The text books contain the syllabus and chapter-wise break-up to enable teachers to teach step-wose and facilitate learners to grasp and master the skills of the non-native language. According to Horvath Ova (2014) and Wang (2017), the teachers concerned with EFL teaching prepare teaching notes for classes based on the prescribed textbooks and students also are primarily expected to learn from those textbooks. The practice in Saudi schools is to literally and solely follow the textbooks assigned by the Ministry of Education. These books represent the main and only source of language knowledge and practice. So, it is important that the textbooks include all the necessary materials, tasks and practice activities that help students achieve success in the language and catalyze their language learning.

The language learning strategies (LLS) are in fact the important inputs among the elements which need to be incorporated in the prescribed language teaching--learning textbooks for EFL curriculum. Such strategies are nothing but innovative ideas and adaptable approaches to smoothen the learning process with activity-related action. These are the views of Oxford (1990) and O'Malley \& Chamo

\footnotetext{
${ }^{1}$ Corresponding Author:

E-mail address: kaalwehebi@iau.edu.sa
} 
(1990); Cohen (2011); and Kumar (2020). CEFR (2011) has expressed opinion that strategies for learning language "means the language user exploits to mobilize and balance his or her resources, to activate skills and procedures, in order to fulfil the demands of communication in context, and successfully complete the task in question in the most comprehensive or most economical way feasible depending on his or her precise purpose" (p.57).

Hajar and Wray (2017) and Kumar (2021), in their study have come to opine that it is worth emphasizing the importance of including suitable and carefully prepared learning material for facilitating both the learning and teaching EFL in Schools. They have stressed the need to incorporate Language Learning Strategies (LLS) for guidance of teachers and to make learning by students a pleasure. According to them, LLSs is to be incorporated in learning materials in cognitive, metacognitive, affective and social categories since they can have a focal role to play in creating thinking language learners who are capable of directing the processes of their own L2 learning and achieving their desired goals. Furthermore, Labelle (2010, p. 366) asserted that selecting books with proper care is important for the language teacher and those books must contain well chosen and LLSs and also the widest possible assortment of LLSs for the L-2 (EFL) learning-teaching to promote proficiency in the non-native language. The selected books, according to him, would not only better engage the learners of EFL but also serve as motivators.

Language learning strategies (LLS) have a positive relationship with language proficiency as indicated by the results of many research studies (Askari, 2014; Habók \& Magyar, 2018; Yolanda \& Zenotz, 2018; Taheri et al. 2020). LLSs also have a significant positive effect on developing learners' motivation to learn the language and their autonomy. (Dörnyei, 2005; Popescu \& Cohen-Vida, 2014, Alzubiet al., 2019; Iamudom \&Tangkiengsirisin, 2020).

The inclusion of LLS in textbooks also conforms to the learning outcomes identified by the Saudi Framework for Qualifications introduced in 2018, which fosters the importance of developing learners' autonomy, and responsibility for their own learning. Hence the need to review the EFL textbooks in Saudi schools to evaluate how far they provide instructions and use of LLS that assist in achieving the educational objectives (stated in the National Framework for Qualifications) and overcoming the problems encountered in the process of teaching-learning of EFL (English as Foreign language) that is non-native language in not only in Saudi secondary schools but also at all levels of education; and even in the Kingdom as a whole. Studies have indicated, and teachers' observations reveal to make it abundantly clear that the Saudi students do not possess desired level of foreign language proficiency, more specifically of EFL. The outcomes of diverse research studies, notably by Alrabai (2016); Asif (2017); Abdelaziz (2018); Alhamad (2018); and Al-Ahdal (2020), have made elaborate comments and given opinions on the subject including the fact disclosed by which they have remarked the shortcomings in students in the matter of learning English. They have also drawn attention to the fact that the teachers also suffer from the lack of SSLs on their back to push up the morale of learners and keep motivating them. As of now, they point out that teaching EFL in Saudi Arabia which obviously is the non-native language, is concomitant of the traditional methods focused on repetition and memorization of vocabulary (words) and grammar structures, with little or no attention is given to providing adequate or proper practice in language skills. As a result, students lack motivation to actively participate in language classes and feel that learning English is difficult, challenging, and disappointing. The researchers confirm through their observation this low EFL proficiency through by on the spot studies in schools while supervising student teachers' field internships. There have been LLS studies on motivation, learning success, and foreign language anxiety by many authors, notably by Kakoty (2020), Habók and Magyar (2018), Cesur (2011). They have successfully shown that LLS (Language Learning Strategies) are responsible for bringing about better learning achievement by Students in the foreign language. Therefore, this study hypothesizes that incorporating LLS in the 
school textbooks would equip both teachers and students with the tools for success in the foreign language. The presentation of the strategies in the textbooks will urge teachers to pay attention to them and provide students with many opportunities to practice the language on their own, hence developing their language and language learning skills.

\section{Review of Literature}

\subsection{Language Learning Strategies and Language Textbooks}

For more than two decades, research has indicated positive effects of LLS on developing learners' proficiency in all language skills Popescu, and Cohen-Vida (2014) concluded that communicative strategies could help learners in enhancing their skills in 3 Rs, more particularly in boosting their confidence in fluency of speaking and develop interest in better communicative interaction. Findings of a study by Taheri et al. (2020) indicated that compensation, affective, and cognitive strategies contributed to the high achievement of all language skills for Iranian students in learning non-native language (EFL). Habók and Magyar (2018) have indicated after undertaking study that language learning interest in the school students gets increased by implementing LLSs. They found this result in their study on secondary school students in Hungary. Ruiz de Zarobe and Zenotz (2018) support this view when the say that reading strategy instruction improved reading comprehension of young learners in Basque country and maintained this improvement over a two-year period.

For these significant benefits of LLS, many researchers and educators recommended incorporating learning strategies into materials and programs to pay attention to these strategies in language teaching. Vettorel (2018) emphasized the importance of EFL material including activities that raise students' awareness and orientation towards LLSs (Language Learning Strategies) with beneficial bearing upon factors such as communication proficiency and reading skills enabling them to be fully integrated into the learning process of English language which is non-native language but now emerging fast as International Language (EFL) for inter- state interaction in all economic, social and humanitarian fields. English is no doubt a Second Language (ESL). There is, therefore, need to introduce LLSs to undertake practices in the learning atmosphere in schools with the objective of facilitating development of necessary capability in communicative process. Taheri et al. (2020) have undertaken studies in this regard and they have come out to suggest that the teachers responsible for imparting instruction and introducing activities in EFL learning by school students may work for integrating teacher-learner duo through selected strategies and motivate them for taking interest in learning the EFL. For this to happen, classroom management with suitable material and by following pre-determined strategies is very significant factor. The researchers add that it requires commitment, encouragement and an atmosphere of fearless learning to be created by the teachers and the authorities. Further, they state that approaches to be followed, strategies to be chosen and the whole learning process have to be shared with the EFL learners so that they get mentally prepared to put in their best in learning EFL without inhibition. The students may also be given freedom to choose and use these strategies with intent of enhancing their interest in learning skills in regard to EFL as it would bring about their commitment to achieve. Alzubi et al. (2019) conducted study and gave their view that by attempting proper integration of the training program format in the matter of using LLSs in the design of the EFL curriculum, enmeshing the teaching and learning methods, and with an eye on empowering EFL learners to enable them to determine their own course/direction in respect of learning reading skills in EFL appears the best fit.

"In fact, the idea of combining learning strategies with curriculum guidelines has been developed in some countries such as the Common European Framework of Reference for Languages: Learning, 
teaching, assessment (CEFR) in Europe (Cambridge, 2011), the Benchmarks in China (MOE, 2011), and the Competence Indicators in Taiwan (MOE, 2008)". (Wang, 2017).

Popescu and Cohen-vida (2014) highlighted the role of teachers in learning strategies instruction. They explained that teachers have ...

There is no gainsaying the fact that the educators, more particularly the EFL teachers, have both duty and responsibility for guiding the EFL learner-students by first creating awareness of the LLSs and then engaging themselves in the selected learning process with LLSs in view for the purpose of developing enthusiasm in the learners. The learning strategies become effective for students to learn the second language that is not their native language; it is true of EFL (Learning of Foreign Language). Well chosen and properly implemented LLSs are aimed at making EFL learners proficient in communicating. Not only this, the teachers have to be given freedom to select LLSs and desired material and equipment to integrate the teacher-learner group for cohesion and mutual appreciation of the skill development objective. Given freedom and encouraging group interaction among the studentlearners, the EFL learners would feel integral part of learning and they would enjoy autonomy and bring about commitment and learning spirit. All in all, the EFL learners would emerge a self-help group, keen to develop reading, writing and communication skills with the help of teacher-guides and with the support of needed infrastructure. I can say with conviction that LLSs play important part in encouraging learners and thus infuse spirit of self-learning in the. The learners will feel important in implementing learning activities in bid to create autonomy and embark on the path of learning themselves.

There are two approaches for presenting LLS in language classes and textbooks: explicit instruction and implicit use. Explicit instruction means giving a direct explanation of each learning strategy presenting its name, explaining its steps, and using it in different language tasks. According to AlAhdal \& Al-Ma'amar, (2015); and Bueno-Alastuey \& Agullo (2015), implicit instruction means any questions or instructions in the language activities. In this, the learners are choose learning strategy (or strategies) to learn the EFL (or any other non-native language) and implement it/them in their earnest hope to learn better and with interest. They add that no mention may be made with any specificity to the chosen strategies and also no mention may be made by the learners as to the manner in which those strategies were used by them. In such freedom, stereotype adherence to the selected strategies is avoided and the strategies may rather get evolved with some change or emphasis.

Wang (2017) confirmed that LLS instruction needs to be clear and explicit. "The more explicit the instruction is, the more successful learning will be" (Oxford, 2017). Explicit instruction of strategies by explaining their meaning, advantages and use to learners would increase learners' awareness of their own learning process and they will become more autonomous. This means that learning will continue outside the classroom. Wang suggests beginning strategy instruction in elementary school, as it will help learners continue to learn effectively when they study in junior, senior, high school, and university. (p. 57)

These call for integrating LLS in language materials and instruction aroused the interest of researchers to analyze EFL text books to find whether or not they introduced LLSs and also did analysis to see the frequency and variances in those selected and implemented strategies. Hajer et al (1996) conducted study on the subject. He made effort to analyze the learning strategies that had most frequencies and were contained in the both the second and foreign language text books in the United States, the United Kingdom, and the Netherlands. The analysis was based on Oxford's (1990) taxonomies of learning strategies. The results showed that cognitive strategies were the most frequent ones and meta-cognitive strategies appeared next. They also identified the differences in strategies between the countries and suggested that further international comparisons should be made. 
La Belle (2010) analyzed the introduction of LLSs in the middle school curricula for EFL in Milwaukee, Wisconsin, USA to find the selected LLSs that served as guidelines to the EFL teachers when they undertook the job of evaluating books, after which they gave them guidance on specific and effective criteria in regard to selecting materials with wide range of learning strategies of second language (such as EFL). He found from his study spread over large number of books that only $22 \%$ of them had a range of second language (L2) learning strategies that ranged from good to excellent scale. Other books contained no LLSs at all.

Taušová undertook study on the subject in 2011 in Czech Republic. He made effort to prescribe a systematic evaluation of language learning strategies with regard to their receptivity of skills contained in the prescribed second language (L-2) text books of German language. It was the second language that was used by teachers for teaching beginners at lower secondary level in primary schools. The lady researcher (Tausova) made analysis of two books out of the six prescribed textbooks. All those six books had approval from the Czech government. Tausova made effort to prepare a list of teachinglearning strategies with the largest frequencies that were used, modified, and selected. Those were selected and listed from already existing systems. She classified those strategies into categories for ease of reference. She engaged herself in personal observation and study of text books in use. She made investigations into those strategies which were concerned with listening and reading of the language. She did so within the first 34 pages of each textbook as well as of the corresponding students' book. She showed that more listening strategies were contained in both books as compared to the reading strategies. She also disclosed that over $50 \%$ of all strategies were related to the only classroom stage, not related to the pre or post stages.

Kuzuya (2014) made his analysis of government approved English language text books meant for the senior high school EFL learner-students in Japan. The analysis was based on Chamot's (2009) categories of learning strategies. The researcher arrived at the conclusion that showed a lack of metacognitive strategies which cast upon the ELF senior high school English teachers the duty of developing the relative student-oriented activities based upon the textbooks to attain the goals set for the course of study.

Horváthová, B. (2014). Investigated into the implementation of language learning strategies into a series of second foreign language textbooks (Deutsch.com 1, 2, 3) approved by the Slovak government. The strategies were used for teaching German at lower secondary and secondary levels who already had experience of learning foreign languages (English) and evinced interest in learning German language (L-2). She made effort to find whether the explicit learning strategies implemented by the teachers of second language made progress across the three course books. She also desired to find if there any changes made in the strategy categories considering the level of individual course books. Her study found that there were one hundred-forty explicitly taught second language learning strategies. She disclosed that most of those strategies were related to reading, speaking, grammar, and vocabulary. She said that the strategies related to listening, writing and pronunciation were slightly less represented. She concluded that there was function-based approach in teaching-learning the second language (EFL). She stated in her report that cognitive strategies $(63 \%)$ and meta-cognitive strategies (proximately 32\%) dominated over social and affective strategies.

Another study by Bueno-Alastuey \& Agullo (2015) searched for the explicit presentation or the implicit use of the second language learning strategies in Spain. The researchers have used for their reference the strategies listed out by Oxford in 1990. Their analysis aimed at finding the strategies that were applicable to the two oral skills: listening, and speaking kills. Their study disclosed limited representation of explicit instruction with regard to second language learning strategies for both listening and speaking skills. They also found more provision/prescription of regarding implicit use of the L-2 teaching-learning strategies in the units of the text books as compared to those found in the 
textbooks or in the support material prepared for practice. In conclusion, the researchers showed that second language (L2) learning strategy, relative instruction, teacher-taught competence, and strategyuse might be insufficient for encouragement and motivation in those textbooks.

Wang did a study on the subject in 2017 by subjecting as many as 34 English text books prescribed by the government for teaching-learning second (L-2) at the elementary and junior high schools in Taiwan. Wang based his analysis on the research guidelines provided by study conducted by O'malley and Chamot's in 2009. In the latter study, reference data for elementary school English text books in Japan was provided. The results of study by Wang indicated that the activities for evaluation strategy could be applied to elementary school English text books in Japan. It was also stated that those strategies were intended to create elementary school learners' awareness about the second language (non-native language) learning process as well as to encourage rather develop independent (fearless) and autonomous (self-managed) learning under the open learning atmosphere and guidance of the language teacher.

It is evident from the above presentation of the previous researches on content analysis of EFL textbooks that few books provided explicit instruction on LLS, and most books implicitly used strategies in the language activities. It has also come to light in the above studies that social and affective strategies were used less as compared to the cognitive, meta-cognitive, and memory strategies.

This study aims to analyze the content of the series of Mega Goal EFL textbooks which were newly assigned for the Saudi secondary schools in the academic year 2020/2021. This analysis intends to see whether these books present or make use of the LLS, and to answer the following questions:

1. What are the vocabulary learning strategies (VLSs) used in the content of the Mega Goal EFL Textbooks?

2. What are the reading strategies used in the content of the Mega Goal EFL Textbooks?

3. Which production (speaking and writing) strategies used in the content of the Mega Goal EFL Textbooks?

4. How does the use of LLS progress in the six books of the Mega Goal set?

\section{Methodology}

The methodology adopted for the present study consisted of making effort to analyze the content of EFL text books (Mega Goal) prescribed for the Saudi secondary Schools with regard to teachinglearning EFL (L-2) with focus on finding provision in those text books regarding explicit instruction and implicit use of language learning strategies (LLS). Only secondary data was used for the study (Previous studies and published works of various authors).

A written exercise containing 24 questions was administered to the secondary class students to elicit their responses regarding use of FLL strategies and other relative factors. Oral communication was also undertaken. A few interviews of teachers were also taken.

\subsection{The Sample}

The study includes the series of Mega Goal EFL textbooks includes six books for the six levels of secondary school. Each book has one introductory unit, six main units and two expansion units. Each of the main units includes 13 activities (2 listening, 1 reading, 1 writing, 3 speaking activities: 1 vocabulary; 2 grammar; 1 pronunciation; 1 project and 1 self- reflection). Each expansion unit gives language review of three units, 1 vocabulary, 1 reading and 1 writing activities and one project. 
There are two approaches to content analysis: the quantitative approach and the qualitative approach (Cohen et al., 2007). This study used the qualitative method because it provides richer results and gives a clear picture of how LLS are presented in the analyzed set of textbooks. The quantitative approach was not used in our analysis because the Mega goal books follow the same structure and the same types of implied strategies in its activities all through the units of the books. So, the number of the implied strategies will be the same number of the units in the six books. The unit of analysis comprised the instructions given for the vocabulary, reading, speaking, and writing activities in the books.

There are three approaches to content analysis of textbooks seeking for LLS: the function approach, the skills-based approach, and the learning vs use approach (Cohen \&Weaver, 2005). This study used the function approach (cognitive, meta-cognitive, social and affective functions of LLS) and the skillsbased approach. It focused on analyzing the reading, speaking, and writing skills and vocabulary because they are very necessary for preparing secondary school students for their studies in English at the university level.

The first step in the content analysis method was selecting the LLS suitable for the secondary school Saudi learners. Three lists of strategies were developed. The first list included 24 vocabulary learning strategies (VLS) adapted from Ghalebi et al (2020). List 2 included 20 reading strategies adapted from Mokhtari and Sheorey (2002). List 3 included 16 communication strategies related to the productive skills: speaking and writing in English. This list was adapted from Tung (2017) which is based on Chamot's taxonomy of learning strategies (2009).

The lists were reviewed by a validity panel that consisted of three secondary school teachers and two faculty members. The purpose of this review was to make sure that: a. the strategies are formed clearly, precisely, and accurately; b. the strategies are suitable for the secondary school students. Based on the feedback from the panel, some strategies marked as 'not suitable' were deleted and some 'unclear' strategies were modified. Teachers who reviewed these lists expressed their admiration of the strategies and that they benefitted from them, and opined they really needed to learn about such strategies.

\subsection{Data Collection Tool}

In this study, the researchers developed coding instruments using the final lists of strategies and analyzed two units in each of the six textbooks of the Mega Goal set. (Each researcher coded two units in three textbooks). The initial review of the books showed that they did not provide any explicit instruction of the LLS. So, the researchers' analysis focused on the implicit strategies contained in the English language text books. The instructions were given in the vocabulary, reading, and writing and speaking activities in the analyzed units were reviewed to see if they matched or made use of the selected learning strategies.

\subsection{Data Analysis}

A third coder (a faculty member) analyzed and coded a sample of one unit in two textbooks (books 1 and 4) to ensure reliability. Any discrepancy in coding was discussed to reach a consensus on the meanings of the instructions given in the activities and their matching to the corresponding strategies.

In their study on the subject, Wu and Barsalou (2009) reported the outcome of their study based on the responses in percentage terms. Cohen (1960) has disputed the working out of the result of analysis in percentage terms. According to him, the outcome in percentages was not reliable due to failure to explicitly track the strategies. Spooren and Degand (2010) have also supported this view. They state that in case of the interpretation of the under-scrutiny phenomenon being critical (unlike the formal 
characteristics), there is high possibility of low concordance. The same observation or opinion is true when a content analysis is done to examine linguistic data. It is observed that interpretation is likely to differ between coders rather than formal data characteristics. The reason is that these interpretations involve a degree of random guessing. Therefore, various researchers claim that the interpreter's agreement should be preferred to the percentages. The argument advanced is that the interpreter's agreement considers perspective and balances it in the spontaneous manner, not by design. However, there is another view. It states that in cases where the coding scheme is straightforward, and the decision is confined to a few possible categories (e.g., a team of doctors, who must decide between the limited number of treatment alternatives) the percentages display reliable results (responses). So, in such circumstance, the percentages agreement could still be valuable. Thus, in these circumstances, coders (i.e., researchers) are well-trained and experienced to keep the frequency of occurrence of random devices low. However, the annotations are more likely to be based on devaluation when the coding system covers many categories.

In the following section, the researcher of the present study has presented the result of content analysis showing the types of LLSs implicitly used in the EFL Mega Goal textbooks.

\section{Discussion and Results}

In this study, the researcher has employed non- inferential descriptive analysis for identifying the categories of strategies applied in the Mega Goal secondary school EFL textbooks.

Table 3.1. Provides the responses/answers to question one: "What are the vocabulary learning strategies used in the Mega Goal textbooks?" It displays the VLS that were implicitly used in the books.

\begin{tabular}{|c|c|c|c|c|c|c|c|}
\hline \multirow[t]{2}{*}{$\mathbf{S}$} & \multirow[t]{2}{*}{ Vocabulary Learning and memorizing Strategies } & \multicolumn{6}{|c|}{ books } \\
\hline & & 1 & 2 & 3 & 4 & 5 & 6 \\
\hline 1 & Check the form of the new words (e.g., find if a word is a verb, noun, adj., adv., etc.) & I & & & I & & \\
\hline 2 & $\begin{array}{l}\text { Write all the word derivatives that you know (adjective: impossible, possible, } \\
\text { possibility, possibly, etc.) }\end{array}$ & & & & & & \\
\hline 3 & $\begin{array}{l}\text { Use pictures or visuals of your choice to help you find the meaning and recollect the } \\
\text { word relating to it. }\end{array}$ & & & & & & \\
\hline 4 & Give the meaning of the new word from context. & & & & & & \\
\hline 5 & $\begin{array}{l}\text { Ask the teacher or a classmate to give you a definition or a sentence to help you to } \\
\text { give the meaning of the new word. }\end{array}$ & & & & I & I & I \\
\hline 6 & Make your own definition (meaning) for the word. & & & & & & I \\
\hline 7 & Discuss the word with your classmates & & & & 1 & I & 1 \\
\hline 8 & Use dictionary to find the word and its meaning. & & & & 1 & I & I \\
\hline 9 & Create a mental image of the word's meaning. & & & & & & \\
\hline 10 & Connect the word to a personal experience. & & & & & & \\
\hline 11 & $\begin{array}{l}\text { Connect the word to other words with similar or opposite meanings (synonyms or } \\
\text { antonyms). }\end{array}$ & & & & I & I & I \\
\hline 12 & Group the words together according to a specific category. & & & & & & \\
\hline 13 & Use new words in sentences and paragraphs. & & & & I & & \\
\hline 14 & Study the spelling of a word and memorize it. & & & & & & \\
\hline 15 & Listen to the sound of the new word & & & & & & \\
\hline 16 & Read the new words aloud when you first meet them. & & & & & & \\
\hline 17 & Use physical action (gestures, body language) to connect a word to its meaning. & & & & & & \\
\hline 18 & Repeat saying the words aloud many times (minimum 10 times) & & & & & & \\
\hline 19 & Write the words many times (minimum10 times) & & & & & & \\
\hline 20 & Use flashcards to record new words & & & & & & \\
\hline 21 & Take notes or highlight new words in class, or outside the class. & & & & & & \\
\hline 22 & Keep a vocabulary notebook & & & & & & \\
\hline 23 & Use English-language media (songs, movies, the internet) & & & & & & \\
\hline 24 & Remember the word using its affix part (im-, un-, -able, - ful, -ment, ex-) & & & & & & \\
\hline
\end{tabular}


In the above table, the coloured rows (in gray) are the strategies that are not used by any EFL related book. The table clearly shows that the books 2 and 3 (Grey coloured space/column) do not use any strategy.

It is clear from the above table that only eleven out of twenty-four vocabulary strategies are implicitly used in the vocabulary activities in the entire set of books. These eleven aspects represent important behaviors required for learning vocabulary. They included: identifying the speech, the new word, meaning from context, using words in context, working with others (partners or the teacher), and using a dictionary.

However, other aspects in vocabulary strategies which are also necessary in vocabulary learning never appeared in the entire set of books. They included using pictures or visuals to guess the meanings of words and remembering them; making one's own mental images to represent the meanings of words; connecting words to personal experience; connecting words to physical actions; using media; repeating words orally; and analyzing words by breaking them into roots and affixes. All these techniques are simple and suitable for high school learners. They are very necessary techniques that help students interact using the new words intensively which leads to better understanding of word meanings and use, and hence, keep words in memory for longer time. If students lack this intensive interaction with the words, they will have difficulty to construct meanings and, will easily forget words.

Table 3. 2. Depicts responses/answers to question two: "What are the reading strategies used in the Mega Goal EFL Textbooks?". The table shows the strategies used in the six analyzed books.

\begin{tabular}{|c|c|c|c|c|c|c|c|}
\hline Rea & ding Strategies & & & & & & \\
\hline & Pre-Reading Strategies & 1 & 2 & 3 & 4 & 5 & \\
\hline 1 & $\begin{array}{l}\text { Preview the text before reading it } \\
\text { Read the topic or heading of the passage } \\
\text { Look at the pictures, graphs, maps, diagrams, etc., of the passage }\end{array}$ & & & & & 1 & \\
\hline 2 & Use prior knowledge to understand the text & & & & 1 & 1 & \\
\hline 3 & Read the first sentence of each paragraph & & & & & & \\
\hline & While-reading strategies & & & & & & \\
\hline 4 & Pay attention to the parts of sentences such as phrases, clauses, subjects, and objects & & & & & & \\
\hline 5 & Link information in one sentence with information from the preceding ones & & & & & & \\
\hline 6 & Read the whole passage quickly to understand the main idea & & & & & & \\
\hline 7 & visualize the information you read & & & & & & \\
\hline 8 & $\begin{array}{l}\text { Make predictions: Anticipate information to come or make logical guess about what } \\
\text { will happen in a written or oral text }\end{array}$ & & & & & & \\
\hline 9 & $\begin{array}{l}\text { Take notes by highlighting or underlining the important ideas while reading the } \\
\text { passage }\end{array}$ & & & & l & 1 & \\
\hline 10 & Confirm predictions & & & & & & \\
\hline & Post-reading strategies & & & & & & \\
\hline 11 & $\begin{array}{l}\text { Make inferences: Use context to figure out meaning or read and listen between the } \\
\text { lines }\end{array}$ & & & & & & \\
\hline 12 & $\begin{array}{l}\text { Check or evaluate your comprehension by answering questions, designing a graphic, } \\
\text { labeling a picture or filling in a table using information from the text }\end{array}$ & & & & I & 7 & \\
\hline 13 & Summarize: Create a mental, oral, or written summary of information & & & & & 1 & \\
\hline
\end{tabular}

Form the above table, it can be noticed that the rows that are coloured in gray are the strategies that are not used by any book. The books 1, 2, 3 do not use any of the many reading strategies.

It is evident from the above that the books provide implicit use of most of the reading strategies such as: previewing texts, using prior knowledge, skimming, taking notes, and evaluating one's comprehension of texts. However, some aspects of reading were never used, although they are also 
crucial for developing students' reading skills. These aspects are; making predictions, confirming predictions, and visualizing the information of the texts.

Table 3.3. Displays the aspects of oral and writing strategies that could be implied from the instructions of the speaking and writing activities in the six books, to answer research question 3 of this study.

\begin{tabular}{|c|c|c|c|c|c|c|c|}
\hline & \multirow{2}{*}{$\begin{array}{l}\text { Oral and writing Strategies } \\
\text { Meta-cognitive Strategies }\end{array}$} & \multicolumn{6}{|c|}{ book } \\
\hline & & 1 & 2 & 3 & 4 & 5 & 6 \\
\hline 1 & Plan/Organize your work: (Set goals or plan how to accomplish the task). & & & & & / & I \\
\hline 2 & Monitor your work by checking your progress on the task. & & & & / & / & \\
\hline 3 & $\begin{array}{l}\text { Evaluate your work by assessing how well you have performed or how well you have } \\
\text { used learning strategies. }\end{array}$ & & & & / & I & I \\
\hline \multirow[t]{2}{*}{4} & $\begin{array}{l}\text { Manage your own learning by arranging the conditions that help you learn or focus your } \\
\text { attention on the task. (ex. Choose the time and place that is suitable for you to learn). }\end{array}$ & & & & & & \\
\hline & \multicolumn{4}{|l|}{ Task-based strategies } & & & \\
\hline 5 & $\begin{array}{l}\text { Use background knowledge: (Think about and use what you already know to help you do } \\
\text { the task and identify what to say or what to write). }\end{array}$ & & & & I & & I \\
\hline 6 & Personalize: Relate your life experiences, beliefs, and feelings to the task. & & & & / & / & I \\
\hline \multirow[t]{2}{*}{7} & $\begin{array}{l}\text { Substitute/paraphrase: Use synonym or descriptive phrase for unknown words or } \\
\text { expressions. }\end{array}$ & & & & & & \\
\hline & \multicolumn{4}{|l|}{ Use your organizational skills strategies } & & & \\
\hline 8 & Find and apply Patterns: (Ex. Recognize/apply grammar rules). & & & & & / & \\
\hline 9 & $\begin{array}{l}\text { Use selective attention: (Focus on specific information, structures, keywords, phrases, or } \\
\text { ideas). }\end{array}$ & & & & I & / & I \\
\hline 10 & Make notes: (Write down words and ideas to include in speaking or writing). & - & & & I & / & I \\
\hline 11 & Use graphic organizers: (Use or create visual representations of important concepts). & - & & & I & I & I \\
\hline \multirow[t]{2}{*}{12} & $\begin{array}{l}\text { Access information sources: (Ex. Use the dictionary, use the Internet, and other reference } \\
\text { materials. }\end{array}$ & & & & / & / & I \\
\hline & \multicolumn{4}{|l|}{ Social/affective strategies } & & & \\
\hline 13 & $\begin{array}{l}\text { Cooperate: (Ex. Work with others to complete tasks, build confidence or give and } \\
\text { receive feedback). }\end{array}$ & & & & I & I & I \\
\hline 14 & Self-talk: (Ex. Reduce your anxiety by reminding yourself of your progress and goal). & & & & & & \\
\hline
\end{tabular}

From the above, it is clear that the books 1,2,3 do not use any of oral and writing strategies. An analysis of the books showed that almost all the strategies in the table are implicitly used in the speaking and writing activities except 1,2,3 books. All the strategies in the meta-cognitive group are used except one (managing one's learning). Then, all the strategies under the task-based category and in the group "using organizational skills" are used in the activities except substitute/paraphrase strategy. The social strategy is used in all the oral and writing activities in the books, encouraging students to work with partners in planning, monitoring, and evaluating their work. However, no use is found in regard to the 'effective strategy' in the table although it is really important in reducing students' anxiety, especially in oral activities where students always feel stress of making mistakes before peers, in developing learners' inner motivation to learn the foreign language.

To answer question four of the present study, the percentages of strategies use in the books were calculated. The results appear in the following section which outlines the outcome of the reliability test conducted on Mega Goal secondary school EFL textbooks from 1 to 6. 
Table 4.1 below represents the results extracted from the identification of VL and Memory strategies. On the one hand, a maximum of $50 \%$ of VL strategies were employed in Books 5 and 6 , respectively, whereas a minimum of $21.4 \%$ of $\mathrm{VL}$ strategies were applied in Books 2 and 3, respectively. Minimum of $9 \%$ of memory strategies were used in Books 2 and 5, respectively, whereas a maximum of $36.3 \%$ of memory strategies were employed in Book 6. It indicates that VL strategies were extensively applied in the EFL textbooks rather than the memory strategies. Through practice, individuals can take responsibility for their learning and progressively build trust, increase participation, and improve skills. Memory strategies are utilized to assess how they enable EFL students to develop their autonomy and vocabulary over a period of time. The vocabulary learning memory strategy helps EFL students expand their vocabulary and vocabulary competence. In addition, this strategy ensures that language acquisition, in general, is self-reliant and thus, promotes individual autonomy. Without instructor supervision, learners who take over their learning may handle them competently.

Table 4.1. Reliability outcome - Vocabulary learning and Memory strategies

\begin{tabular}{|l|l|l|l|l|}
\hline \multirow{2}{*}{ Books } & \multicolumn{2}{|l|}{$\begin{array}{l}\text { Vocabulary Learning } \\
\text { Strategies }\end{array}$} & \multicolumn{2}{l|}{ Memory Strategies } \\
\cline { 2 - 5 } & $\begin{array}{l}\text { No. of } \\
\text { Aspects }\end{array}$ & $\%$ & $\begin{array}{l}\text { No. of } \\
\text { Aspects }\end{array}$ & $\%$ \\
\hline 1 & 5 & 35.7 & 2 & 18.1 \\
\hline 2 & 3 & 21.4 & 1 & 9 \\
\hline 3 & 3 & 21.4 & 2 & 18.1 \\
\hline 4 & 8 & 57.1 & 3 & 27.7 \\
\hline 5 & 7 & 50 & 1 & 9 \\
\hline 6 & 7 & 50 & 4 & 36.3 \\
\hline
\end{tabular}

Further, Table 4.2 includes the outcome of the investigation of the reading strategies in Mega Goal text books. It is evident from the results that Book 5 contains $60 \%$ of Pre- reading strategies, $72.7 \%$ of While-reading strategies, and 50\% of Post-reading strategies, respectively. In contrast, $20 \%$ of Prereading strategies, $9 \%$ of While-reading strategies, and $75 \%$ of Post-reading strategies are applied in Book 1. The overall outcome indicates that the textbooks were focused on Post-reading strategies rather than Pre-reading, and While-reading strategies.

This study discovers which pre-reading techniques are the most advantageous to enhance understanding and knowledge while dealing with tacit learners by exploring the efficiencies of prereading strategies and recognizing different ways. Personal knowledge building and refining is a prereading strategy. Meaning is generally built on one or more of the following strategies: prediction, inference of language, connection, visualization, priority making, interrogation, and usage of any combination of all or may be just one of these.

Table 4.2. Reliability outcome - Reading strategies

\begin{tabular}{|l|l|l|l|l|l|l|}
\hline \multirow{3}{*}{ Books } & \multicolumn{2}{l}{$\begin{array}{l}\text { Pre-reading } \\
\text { Strategies }\end{array}$} & \multicolumn{2}{l|}{$\begin{array}{l}\text { While - reading } \\
\text { Strategies }\end{array}$} & \multicolumn{2}{l|}{$\begin{array}{l}\text { Post-reading } \\
\text { Strategies }\end{array}$} \\
\cline { 2 - 8 } & $\begin{array}{l}\text { No. of } \\
\text { Aspects }\end{array}$ & $\%$ & $\begin{array}{l}\text { No. of } \\
\text { Aspects }\end{array}$ & $\%$ & $\begin{array}{l}\text { No. of } \\
\text { Aspects }\end{array}$ & $\%$ \\
\hline 1 & 1 & 20 & 1 & 9 & 3 & 75 \\
\hline 2 & 1 & 20 & 2 & 18.1 & 3 & 75 \\
\hline 3 & 2 & 40 & 1 & 9 & 3 & 75 \\
\hline 4 & 2 & 40 & 4 & 36.3 & 2 & 50 \\
\hline 5 & 3 & 60 & 8 & 72.7 & 2 & 50 \\
\hline 6 & 2 & 40 & 11 & 100 & 2 & 50 \\
\hline
\end{tabular}


Finally, Table 4.3 represents the results of the identification of Oral and Writing strategies used in the textbooks. Both Books 5 and 6 applied the maximum number of aspects in Meta-cognitive, Taskbased, Organizational skills, and Social / affective strategies, accordingly. Furthermore, Figure 4.1 illustrates the overall strategies employed in the EFL textbooks.

Table 4.3. Reliability outcome - Oral and Writing strategies

\begin{tabular}{|l|l|l|l|l|l|l|l|l|}
\hline \multirow{3}{*}{ Books } & \multicolumn{2}{l}{$\begin{array}{l}\text { Meta-cognitive } \\
\text { Strategies }\end{array}$} & \multicolumn{2}{l|l|l|}{$\begin{array}{l}\text { Task-based } \\
\text { strategies }\end{array}$} & \multicolumn{2}{l|}{$\begin{array}{l}\text { Organizational } \\
\text { skills strategies }\end{array}$} & \multicolumn{2}{l|}{$\begin{array}{l}\text { Social/affective } \\
\text { strategies }\end{array}$} \\
\cline { 2 - 10 } & $\begin{array}{l}\text { No. of } \\
\text { Aspects }\end{array}$ & $\%$ & $\begin{array}{l}\text { No. of } \\
\text { Aspects }\end{array}$ & $\%$ & $\begin{array}{l}\text { No. of } \\
\text { Aspects }\end{array}$ & $\%$ & $\begin{array}{l}\text { No. of } \\
\text { Aspects }\end{array}$ & $\%$ \\
\hline 1 & 2 & 50 & 3 & 75 & 3 & 50 & 1 & 50 \\
\hline 2 & 2 & 50 & 2 & 50 & 4 & 66.7 & 1 & 50 \\
\hline 3 & 3 & 75 & 3 & 75 & 4 & 66.7 & 1 & 50 \\
\hline 4 & 2 & 50 & 2 & 50 & 4 & 66.7 & 1 & 50 \\
\hline 5 & 4 & 100 & 3 & 75 & 5 & 83.3 & 1 & 50 \\
\hline 6 & 4 & 100 & 4 & 100 & 6 & 100 & 1 & 50 \\
\hline
\end{tabular}

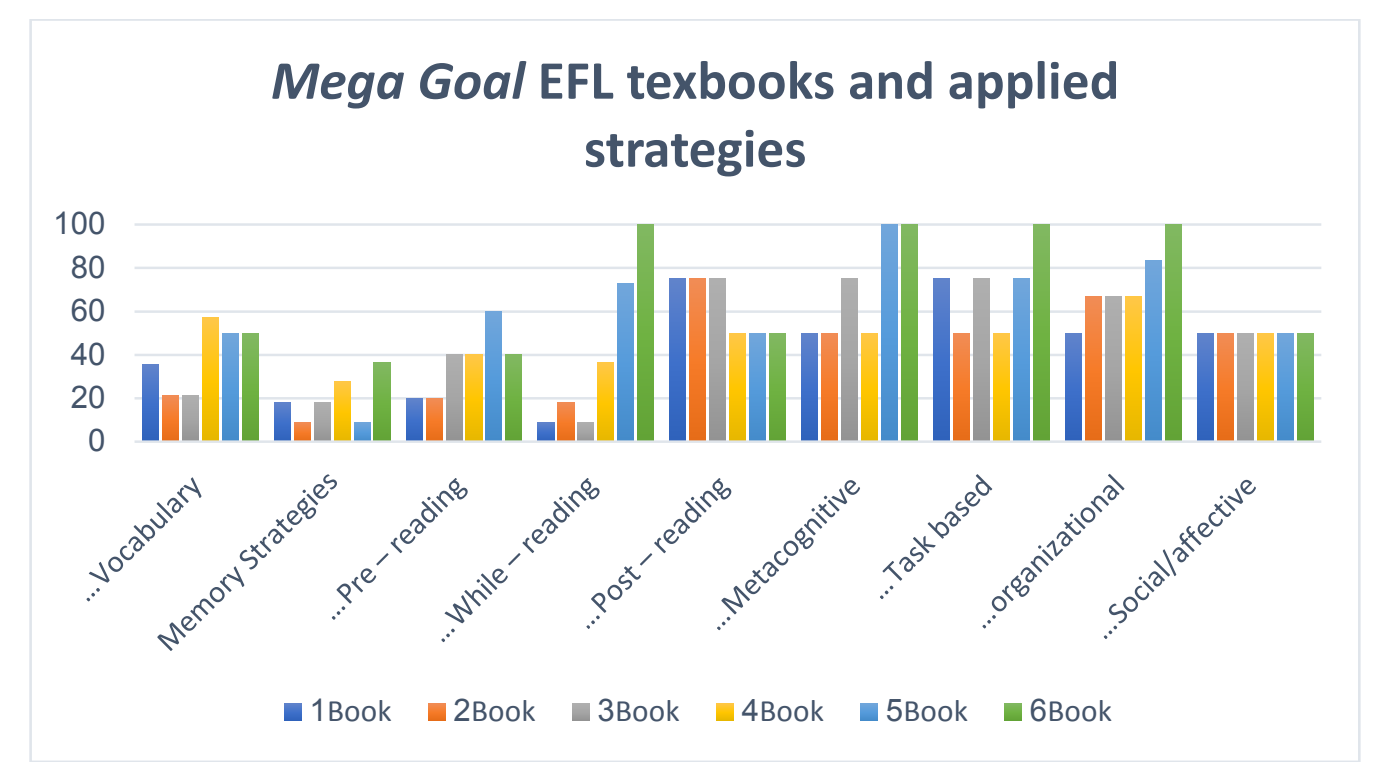

Figure 4.1. Graphical representation of strategies applied in textbooks

As explained in the Methodology section, there is no explicit instruction of LLS in the Mega Goal EFL textbooks from levels1 to 6. This is considered a shortcoming of this set of books since literature affirms that direct, explicit instruction of LLS is more effective (Chamot, 2005). Cohen (2011) and Plonsky (2011) assert instruction strategy occurs when it is explicit. They explained that if students do not receive enough explicit instruction of LLS, they will not have enough knowledge to help them to select the most effective strategies, and they will probably continue using the same strategies over and over again without making significant progress (Plonsky, 2011 \& Anderson, 2005). That is why books that give explicit instruction of LLS are considered "more pedagogically appropriate" because teachers tend to cover what there is in the units first (McGrath, 2006).

Based on the above, the study deduces that Mega Goal books lack one important element of effective language textbooks: the explicit presentation of LLS. This revelation points to a lack of awareness of the importance of L2 learning strategies for successful language performance on the part of publishing houses. According to Bueno Alastuay \& Agulló (2015, p. 32), "Textbook units should offer a wider array of strategies to provide an adequate range of them to help learners decide which one matches the task better depending on the skill developed". 
However, results of the content analysis of the books show that there is only implicit use of some LLS in the instructions of the language activities in the units. This is a strength of these books because if the activities are performed properly as intended, they will help learners practice the learning strategies, even though unintentionally, and so improve their learning performance, develop autonomy, and develop language proficiency. However, this depends on the teacher's education and experience. Teachers might or might not realize the implied strategies or pay attention to them. They might ask the students to do the activities as instructed with no reference to the learning strategies. Students might not realize why it is necessary, how to access extra resources, how to plan for a speaking or a writing task, how to monitor their work, how to evaluate theirs and their partners' work and give feedback, and how to identify the important parts of a text to get the main ideas, etc.

\section{Conclusion}

The present study analyzed a set of six EFL textbooks teaching EFL to secondary school Saudi learners beginning from the academic year 2020/2021. Analysis showed that there was no explicit instruction of any of the learning strategies, and there was only implicit use of the strategies in the instructions of the language activities in the books. These results reflect weak awareness of LLS on the part of the publishers. In fact, LLS explicit instruction in EFL textbooks is recommended by many researchers and educators as it is related strongly to the success in the language and in developing learners' autonomy and ability to control their own learning outside the classroom. Based on this, it is suggested that publishers make some changes in the following editions of the Mega Goal set of books to include direct instruction of the learning strategies; or the entire set may be exchanged with another one that provides explicit instructions of language learning strategies.

One limitation might be raised concerning the analysis procedures followed in the study. In fact, although there were some discussions on the meanings of the strategies selected and the instructions in the books, analysis depended mainly on the coders' judgment on what strategy is implied from the instructions of the analyzed language activities or whether some instructions represent some learning strategies or not.

In order to know more learning strategies in EFL classes, we suggest doing further research on teachers' awareness of learning strategies and how they deal with them in classes in addition to their relationship to students' language achievement and autonomy.

\section{References}

Abdelaziz, A.A. (2018). The reasons behind inefficient English language practices in Saudi Universities. Theory and Practice in Language Studies, 8(9), 1122-1130. http://dx.doi.org/10.17507/tpls.0809.03

Al-Ahdal, A.A.M.H. (2020). Code Mixing in Arabic conversations of college students: A Sociolinguistic study of attitudes to switching to English. Asian ESP Journal, 16(1), 6-19.

Al-Ahdal, A.A.M. H., \& Al-Ma'amari, A. A. H. (2015). Learning Strategies of the Arab EFL Learners: Finding Correlation with Outcomes. Advances in Language and Literary Studies, 6(5), 230-241.

Alhamad, R. (2018). Challenges and induction needs of novice English as a foreign language teachers in Saudi Arabia. International Journal of Education and Literacy Studies, 6(1), 50-60. http://dx.doi.org/10.7575/aiac.ijels.v.6n.1p.50

Alrabai, F. (2016). Factors underlying low achievement of Saudi EFL learners. International Journal of English Linguistics, 6(3), 21-37. http://dx.doi.org/10.5539/ijel.v6n3p21 
Alzubi, A. \& Singh, M. (2017). The Use of Language Learning Strategies through Smartphones in Improving Learner Autonomy in EFL Reading among Undergraduates in Saudi Arabia. International Journal of English Linguistics; 7(6), 59-72 doi:10.5539/ijel.v7n6p59 URL: http://doi.org/10.5539/ijel.v7n6p59

Alzubi, A.A.F., \& Singh, M.K.A. (2019). Investigating reading learning strategies through smartphones on Saudi learners' psychological autonomy in reading context. International Journal of Instruction, 12(2), 99-114.

Anderson, N. J. (2005). L2 learning strategies. In Handbook of research in second language teaching and learning (pp. 781-796). Routledge.

Asif, F. (2017). The anxiety factors among Saudi EFL learners: A study from English language teachers' perspective. English Language Teaching, 10(6), 160-173. http://doi.org/10.5539/elt.v10n6p160

Askari, M.I. (2014). The effect of meta-cognitive vocabulary strategy training on the breadth of vocabulary knowledge. Journal of Academic and Applied Studies, 4(5), 120.https://doi.org/10.14456/nrru-rdi.2018.33

Bueno-Alastuey, M. C., \&Agulló, G. L. (2015). Explicit instruction and implicit use of L2 learning strategies in higher secondary EFL course books. International Journal of English Studies, 15(2), 17-39. https://doi.org/10.6018/ijes/2015/2/218581

Cesur, M.O. (2011). Can language learning strategies predict Turkish university prep class students' achievement in reading comprehension? Procedia Social and Behavoral Sciences, 15, 1920-1924. https://doi.org/10.1016/j.sbspro.2011.04.028

Cohen, A.D. (2011). Strategies in learning and Using a Second Language. Abingdon, England: Routledge/Pearson Education.

Cohen, A.D., \& Weaver, S.J. (2005). Styles and Strategies-based Instruction: A Teacher's Guide. Center for Advanced Research on Language Acquisition. Working Paper Series.

Cohen, L., Manion. L \& Morrison, K. (2007). Research Methods in Education. New York. Routledge

Council of Europe. (2011). Common European Framework of Reference for Languages: Learning, Teaching, Assessment (CEFR) [cit. 2011-06-14] Retrieved from http://www.coe.int/t/dg4/linguistic/Source/Framework_EN.pdf

Dörnyei, Z. (2005). The psychology of the language learner: Individual differences in second language acquisition. New York: Routledge.

Ghalebi, R., Sadighi, F., \& Bagheri, M.S. (2020). Vocabulary learning strategies: A comparative study $\begin{array}{llll}\text { of } & \text { EFL } & \text { learners. Cogent } & \text { Psychology, 7(1), }\end{array}$ https://doi.org/10.1080/23311908.2020.1824306

Habók, A., \& Magyar, A. (2018). The effect of language learning strategies on proficiency, attitudes and school achievement. Frontiers in psychology, 8, https://doi.org/10.3389/fpsyg.2017.02358

Hajar, A. \& Wray, D. (2017). Helping learners learn: Exploring strategy instruction in language learning textbooks. In Tomlinson, B., Masuhara, H. \& Mishan, F. Practice and Theory for materials development for L2 learning. Cambridge Scholars Publishing, 131-148.

Hajer, M., Meestringa, T., Park, Y. Y., \& Oxford, R.L. (1996). How print materials provide strategy instruction. Language learning strategies around the world: Cross-cultural perspectives, 119-140. 
Horváthová, B. (2014). Implementing language learning strategies into a series of second foreign language learning textbooks. Journal of Language and Cultural Education, 2(1), 60-94.

Iamudom, T., \& Tangkiengsirisin, S. (2020). A comparison study of learner autonomy and language learning strategies among Thai EFL learners. International Journal of Instruction, 13(2), 199-212.

Kakoty, A. (2020). LLS use and proficiency: Assamese ESL learner's context. Samrt Moves Journal IJELLH, 8(7), 310-315.

Kumar, T. (2020). Approaches in teaching writing skills with Creative Writing: A TESOL study for Indian learners. TESOL International Journal, 15(5), 78-98.

Kumar, T. (2021). The impact of written visual materials in the development of speaking skills in English language among secondary level students. Journal of Language and Linguistic Studies, 17(2), 1086-1095. Doi: 10.52462/j1ls.76

Kuzuya, J. (2014). Teaching learning strategies to foster students' Zest for Life in the Japanese English teaching context. (Unpublished master's thesis). Graduate School of Global Japanese Studies, Meiji University, Japan.

LaBelle, J.T. (2010). Selecting ELL Textbooks: A Content Analysis of L2 Learning Strategies. Journal of Language Teaching and Research, 1(4), pp. 358-369.

McGrath, L. (2006). Developing eLearning policies at the department level. DigitalCommons@ Kennesaw State University.

Mokhtari, K., \& Sheorey, R. (2002). Measuring ESL students' awareness of reading strategies. Journal of Development Education, 25, 2-10

Mustafa CANER1, Aslihan ÇELIK2. (2020). The Communicative Competence Elements in the Foreign Language Textbooks: A Descriptive Case Study on Turkish and English Textbooks. International Association for Research on Textbooks and Educational Media IARTEM E-Journal, 12 (1) https://doi.org/10.21344/iartem.v12i1.727

O'malley, J. M., \&Chamot, A. U., (1990). Learning strategies in second language acquisition. Cambridge university press.

Oxford, R.L. (1990). Language learning strategies: what every teacher should know. New York: Newbury House Publishers. Oxford, R.L. (2012). Teaching and researching language learning strategies. Harlow: Longman

Oxford, R.L. (2017). Teaching and researching language learning strategies: Self-regulation in context. (2nd Edition). New York: Routledge.

Plonsky, L. (2011). The effectiveness of second language strategy instruction: A meta analysis. Language learning, 61(4), 993-1038. https://doi.org/10.1111/j.1467-9922.2011.00663.x

Popescu, A. \& Cohen-Vida. (2014). Communication strategies for developing the learner's autonomy. Procedia- Social and Behavioral Sciences, 116, pp. 3489-3493. https://doi.org/10.1016/j.sbspro.2014.01.789

Ruiz de Zarobe, Y., \& Zenotz, V. (2018). Learning strategies in CLIL classrooms: how does strategy instruction affect reading competence over time?. International Journal of Bilingual Education and Bilingualism, 21(3), 319-331. 10.1080/13670050.2017.1391745

Spooren, W., \& Degand, L. (2010). Coding coherence relations: Reliability and validity. Corpus Linguistics and Linguistic Theory, 6, 241-266. https://doi.org/10.1515/cllt.2010.009 
Taheri, H., Sadighi, F., Bagheri, M. S., \& Bavali, M. (2020). Investigating the relationship between Iranian EFL learners' use of language learning strategies and foreign language skills achievement. Cogent Arts \& Humanities, 7(1). https://doi.org/10.1080/23311983.2019.1710944

TAUŠOVÁ, K. (2011). Receptivnídovednosti a strategieučení - kategoriálnísystémy pro hodnoceníučebnicněmeckéhojazyka. In V. Janíková, M. Píšová, \& S. Hanušová, Metodologickéotázkyvýzkumuvýukycizíchjazyků. Brno: Masarykovauniverzita, 115-128.

Vettorel, Paola. (2018). ELF and Communication Strategies: Are they taken into Account in ELT Materials? RELC Journal, 49(1), 58-73. https://doi.org/10.1177/0033688217746204

Wang, W. T. (2017). Learning strategies in elementary and junior high school English textbooks in Taiwan. JES Journal, 17(02), 54-68. https://doi.org/10.20597/jesjournal.17.02_54

Wu, L.-L., \& Barsalou, L. W. (2009). Perceptual simulation in conceptual combination: Evidence from property generation. Acta Psychologica, 132, 173-189. https://doi.org/10.1016/j.actpsy.2009.02.002

\section{AUTHOR BIODATA:}

Dr. Kholoud Alwehebi holds a PhD degree in English language Curriculum and Methodology from Princess Nourah Bint Abdulrahman University, Saudi Arabia. She is an Assistant Professor of English language Curriculum and Methodology at the Department of Curriculum and Methodology. Her main research interests include English strategies, developing English language skills and professional development.

Dr. Wafaa Abdel Raouf Ghareeb has a PhD degree in English Language Curriculum and Methodology from Ain Shams University in Egypt. She is an Assistant Professor of Methods of Teaching English in the Curriculum and Methodology Dept., Imam Abdulrahman Bin Faisal University. She is interested in research on language learning strategies, language assessment and active learning. 